Egyptian Journal of Aquatic Biology \& Fisheries

Zoology Department, Faculty of Science,

Ain Shams University, Cairo, Egypt.

ISSN $1110-6131$

Vol. 23(1): 265 -274 (2019)

www.ejabf.journals.ekb.eg

\title{
Effect of Propofol Fresensius 1\% on nervous system ultrastructure of Biomphalaria alexandrina.
}

\author{
Hanan S. Mossalem* and Shereen M. Mansour \\ Department of Environmental Research and Medical Malacology, Theodor Bilharz \\ Research Institute, Egypt. \\ * Corresponding Author: hanan.mossalem@yahoo.com
}

\section{ARTICLE INFO \\ Article History: \\ Received: Jan.16, 2019 \\ Accepted: Feb.8,2019 \\ Online: Feb. 12, 2019}

Keywords:

Propofol fresensius

Nervous system

Biomphalaria alexandrina

Bioindicator

Golgi bodies

\section{ABSTRACT}

This study was aimed to evaluate the effect of propofol fresensius $1 \%$ on the nervous system of Biomphalaria alexandrina snails, which represent the intermediate host of schistosoma mansoni after acute exposure $(5 \mathrm{ml} / \mathrm{L})$ for 24 hours and chronic exposure $(1 \mathrm{ml} / \mathrm{L})$ for $72 \mathrm{~h}$, using scanning and transmission electron microscope. After chronic exposure, visceral ganglion was observed compressed and elongated, not paired with pedal ganglia and its nerves did not contact with it. $1 \mathrm{ml} / \mathrm{L}$ propofol completely blocked synaptogenesis between visceral and pedal neurons. After acute exposure, the varicosities have few granular vesicles, whereas in the chronic exposure, the varicosities were empty and no granular vesicles were found inside it. Poorly developed endoplasmic reticulum, few Golgi bodies, elongated mitochondria, and more intercellular connective space were observed.

\section{INTRODUCTION}

Propofol's main action appears to be as a GABA-A receptor modulator, enhancing GABA-mediated inhibition (Hara et al., 1993). Ketamine is primarily a non-competitive NMDA receptor antagonist, blocking the open receptor at a site within the pore (Orser et al., 1997). In addition, other cellular actions, including effects on nicotinic acetylcholine and5-HT3 receptors (Violet et al., 1997; Browning and Lukowiak, 2008) and ion channels and conductances (Yamakage et al., 1995; $\mathrm{Wu}$ et al., 1997) have been reported for both agents, but these do not explain the excitatory effects described above. Molluscan neurons have been widely used for investigating and screening the effects of pharmacological agents (Girdlestone et al., 1989a,b; Mills et al., 1992; Woodall and McCrohan 2000; Woodall et al., 2003; Nacsa et al., 2015; Bogodvid et al., 2017; Elekes et al., 2018; Wyeth, 2019). This is largely due to their highly accessible central nervous systems (CNS), with 'giant' neurons which can be individually identified from one preparation to the next (Kyriakides et al., 1989). This means that the same neuron with known characteristics as well as identified synaptic connections, can be used to study and compare responses to different agents within an intact nervous system in vitro. Lymnaea stagnalis has been exploited in studies of the actions of inhalation anaesthetics such as halothane, isoflurane and enflurane. All of these agents induce 
full and reversible anaesthesia in the whole animal, measured as a loss of the whole body withdrawal reflex, at clinically relevant doses, with an ED50 close to the anaesthetic requirement of mammals (Girdlestone et al., 1989a). Woodall and McCrohan (2000) showed that the actions of the intravenous anaesthetics propofol and ketamine on animal behavior and neuronal activity in the snail L. stagnalis, particularly in relation to excitatory effects observed clinically. When injected into the whole animal, neither agent induced total anaesthesia. Rather, behavioural activity was enhanced by propofol $\left(10 \_5 \mathrm{M}\right)$ and ketamine $\left(10 \_7 \mathrm{M}\right)$, indicating excitatory effects. When superfused over the isolated central nervous system (CNS), differential effects were produced in two identified neurons, right pedal dorsal 1 (RpeD1) and visceral dorsal 4 (VD4). Resting membrane properties were largely unaffected. However, spike after hyperpolarisation was significantly reduced in RpeD1, but not VD4, with some evidence of increased excitability. In addition, an intrinsic bursting property (post-stimulus burst) in VD4 was altered by propofol $\left(10 \_7 \mathrm{M}\right)$. The results suggest significant excitatory components in the actions of some intravenous anaesthetics, as well as a potential role in modifying excitation and bursting mechanisms in the CNS (Woodall and McCrohan, 2000).

\section{MATERIALS AND METHODS}

\section{Snails}

Biomphalaria alexandrina were collected from irrigation schemes at Giza Governorate, Egypt. The snails were then washed thoroughly with dechlorinated tap water and maintained in the Medical Malacology Laboratory, Theodor Bilharz Research Institute, Egypt, at room temperature $\left(25 \pm 1^{\circ} \mathrm{C}\right)$, in plastic aquaria $(16 \mathrm{x} 23 \mathrm{x}$ $9 \mathrm{~cm}$ ) containing dechlorinated tap water and covered with glass plates. The snails were fed lettuce leaves and blue green algae (Nostoc muscorum). Lettuce leaves were given daily and its amount was adjusted to the number and size of the snails and the algae were added weekly. Snails were examined twice weekly for natural infection up to 6 successive weeks. Uninfected, healthy snails were used in the experimental tests.

\section{Experiment}

Biomphalaria alexandrina breeding from lab generation $7-8 \mathrm{~mm}$ in shell diameter are divided into 3-groups. $1^{\text {st }}$ group exposed for $5 \mathrm{ml} / \mathrm{L}$ propofol fresensius $1 \%$ for $24,2^{\text {nd }}$ group exposed for $1 \mathrm{ml} / \mathrm{L}$ for 72 hours of propofol fresensius $1 \%$ and $3^{\text {rd }}$ group for control then dissected. After dissection of such specimens, the nervous system was drawn under a binocular dissecting microscope to make electronic microscope examination.

Propofol fresensius $1 \%$ is anaesthetic agent for intravenous injection or infusion manufactured by fresensius Kabi Austria GmbHA. 8055 Graz, Austria on behalf of Anesthetic agent.

\section{Scanning Electron Microscope}

Ultrastructure study of central nervous system was fixed by processeding according to Glauert, (1974). They were fixed for $30 \mathrm{~min}$ in $2.5 \%$ glutharaldehyde in PBS buffer at room temperature. All samples were centrifuged gently, washed 3 times in PBS, postfixed for min in $2 \%$ osmium tetroxide in PBS buffer at $4^{\circ} \mathrm{C}$, and dehydrated in 4 changes of graded alcohol $(50,70,90$, and 100\%) at 5 min gap. Finally pellet was examined on fornvar coating grids by Scanning Electron Microscope (Inspect S; FEI, Holland) illustrating the shape of C.N.S in treated and 
control samples at Electron Microscopy Unite of Theodor Bilharz Research Institute (TBRI).

\section{Transmittion Electron Microscope}

Central nervous system was fixed by immersion in iced $2.5 \%$ glutaraldehyde in $0.2 \mathrm{M}$ phosphate buffered ( $\mathrm{pH} 7.2$ ) for $2 \mathrm{hr}$ and post-fixed in $0.05 \mathrm{M}$ sodium cacodylate buffer and 1\% osmium tetroxide in the same buffer and dehydrated in acetone for embedding in Araldine. Ultra-thin sections from selected blocks were obtained with a Reichert OM-43 Ultratome, doubly-stained with lead citrate and uranyl acetate and examined with a Jeol $100 \mathrm{C}$ Electron Microscope at $50 \mathrm{Kv}$. Semithin sections, approximately 1-2 um in thickness, stained with alkaline toluidine blue, were used for selecting the area of interest.

\section{RESULTS}

\section{1- Scan electron microscope:}

\section{A- Nervous system in control snail:}

The present study revealed that the nervous system of $B$. alexandrina snails consists of a double ring of 9 ganglia and an anteriorly situated pair of buccal ganglia (Fig. 1a). The upper ring consists of the paired cerebral ganglia, paired pleural ganglia, paired parietal ganglia (though left and right ganglia are of unequal size) and the single median visceral ganglion. The paired pedal ganglia lie ventral to this upper ring and are connected to it via the cerebra-pedal connectives and pedal pleural connectives. The pedal ganglia are connected to one another by the dorsal pedal commissure and the ventral pedal commissure. Pleural ganglia have no commissure, but they receive three connectives from cerebral, pedal ganglia and from the visceral loop.

\section{B- Effect of Propofol on morphology of ganglia:}

In control snail, when visceral ganglion (V.G) was soma-soma paired with pedal ganglia (Pe.G), excitatory synapses between V.G and Pe.G develop reliably $(100 \%)$. Neurons were located and they projected thick axons. In the neuropil varicose processes were found juxtaposed thick axons suggesting a close contact with them (Fig. 1b). To investigate whether propofol affects cholinergic synaptic transmission between V.G and Pe.G, recordings were made from the paired cells in the presence of anesthetic. After acute exposure $24 \mathrm{~h}$ in $5 \mathrm{ml} / \mathrm{L}$ propofol, Pedal and visceral ganglia were slightly shrunken and visceral nerves between the cells ending both at the axonal contact point and around the pedal somata (Fig. 1c). In the neuropil varicose processes were found juxtaposed the thin axons. $5 \mathrm{ml}$ propofol reduced synaptic transmission. After chronic exposure $72 \mathrm{~h}$ in low concentration $1 \mathrm{ml} / \mathrm{L}$ propofol, visceral ganglion was compressed and elongated, not paired with pedal ganglia and its nerve did not contact with pedal ganglia (Fig. 1d). Presynaptic action potentials in V.G failed to generate excitatory postsynaptic potentials in Pe.G. $1 \mathrm{ml} / \mathrm{L}$ propofol completely blocked synaptogenesis between visceral and pedal neurons. 

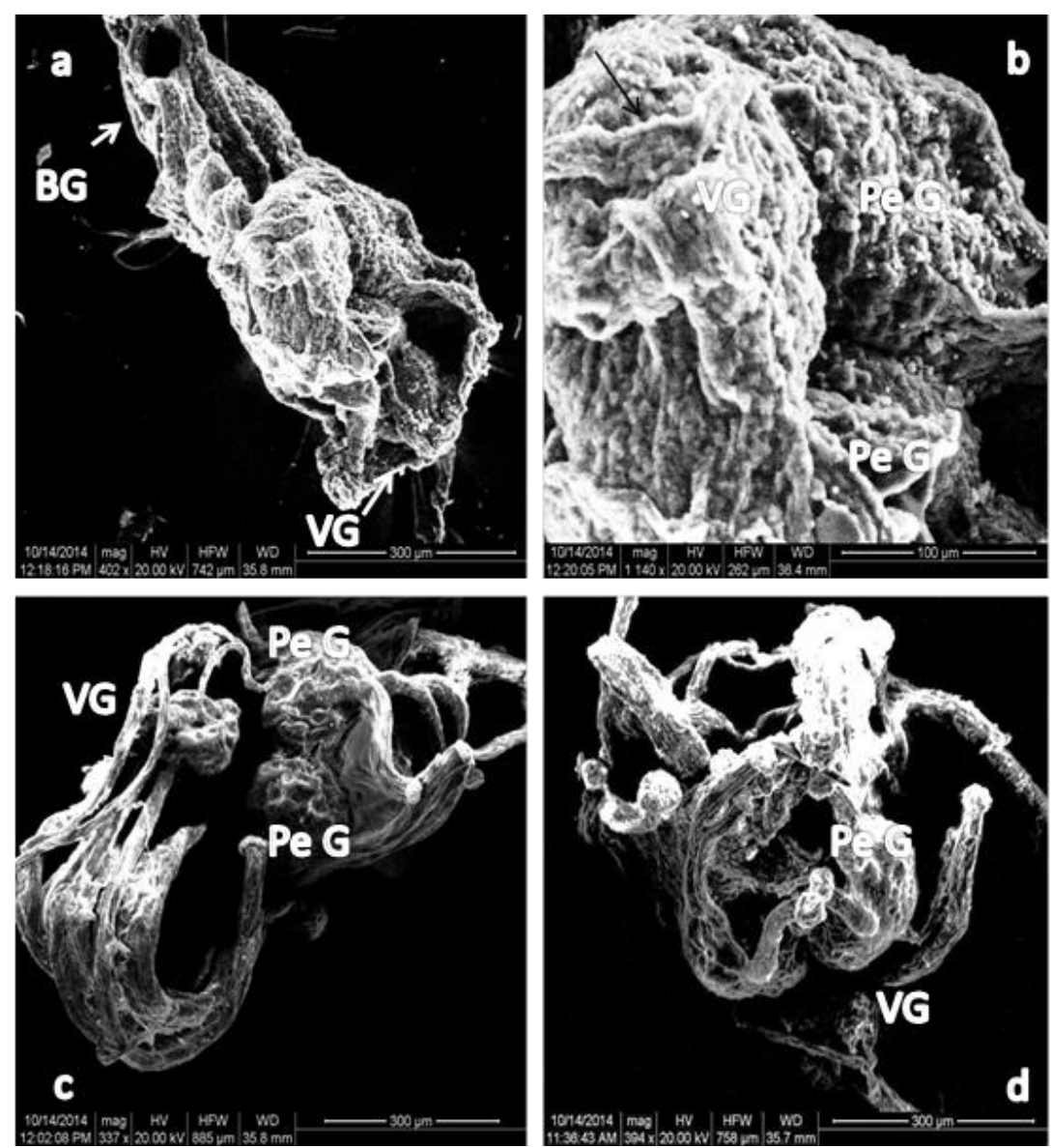

Fig. 1: Scanning electron micrographs of control Biomphalaria alexandrina central nervous system a,b showing normal structure and morphology of ganglia and axons (arrow), buccal ganglia (BG), median visceral ganglion (VG), pedal ganglia (Pe G) . (c) After $24 \mathrm{~h}, 5 \mathrm{ml} / \mathrm{L}$ propofol Pedal and visceral ganglia were slightly shrunken, presynaptic processes ending both at the axonal contact point and around the Pedal somata. (d) After $72 \mathrm{~h}$ in low concentration $1 \mathrm{ml} / \mathrm{L}$ propofol, visceral ganglion was compressed and elongated, not paired with pedal ganglia and its nerve did not contact with pedal ganglia.

\section{2- Transmission Electron microscope:}

\section{A- Ultrastructure of central nervous system:}

The ultrastructure of central nervous system control sections of these ganglia was investigated. Generally, it showed oval nucleus, mitochondria and smooth endoplasmic reticulum sER (Fig. 2a). Active Golgi body and rough endoplasmic reticulum often organized in regular arrays and a great number of free ribosomes. The electron dense neurosecretory granules were observed. These were attributed to the activity of both Golgi apparatus and rER that have the main role in their formation. Varicosities filled with granular vesicles of variable electron density were also observed (Fig. 2b).

\section{B- Effects of propofol on central nervous system ultrastructure:}

After acute exposure $24 \mathrm{~h}, 5 \mathrm{ml} / \mathrm{L}$ propofol effect on ultrastructure elements of the cell where the nucleus became irregular in shape with several indentations in the nuclear envelope and heterochromatin granules against this membrane (Fig. 2c). Figures $(2 \mathrm{~d}, \mathrm{e})$ showed a shrunken process filled with lipid droplets and an increased intercellular connective space. The lipid droplets (L) surrounded by sER. The varicosities have few granular vesicles. Whereas chronic exposure at low concentration $1 \mathrm{ml} / \mathrm{L}$ propofol for $72 \mathrm{~h}$, the varicosities were empty and no granular 
vesicles inside it. Poorly developed endoplasmic reticulum, few Golgi bodies, elongated mitochondria, and more intercellular connective space were observed (Fig. 2f).
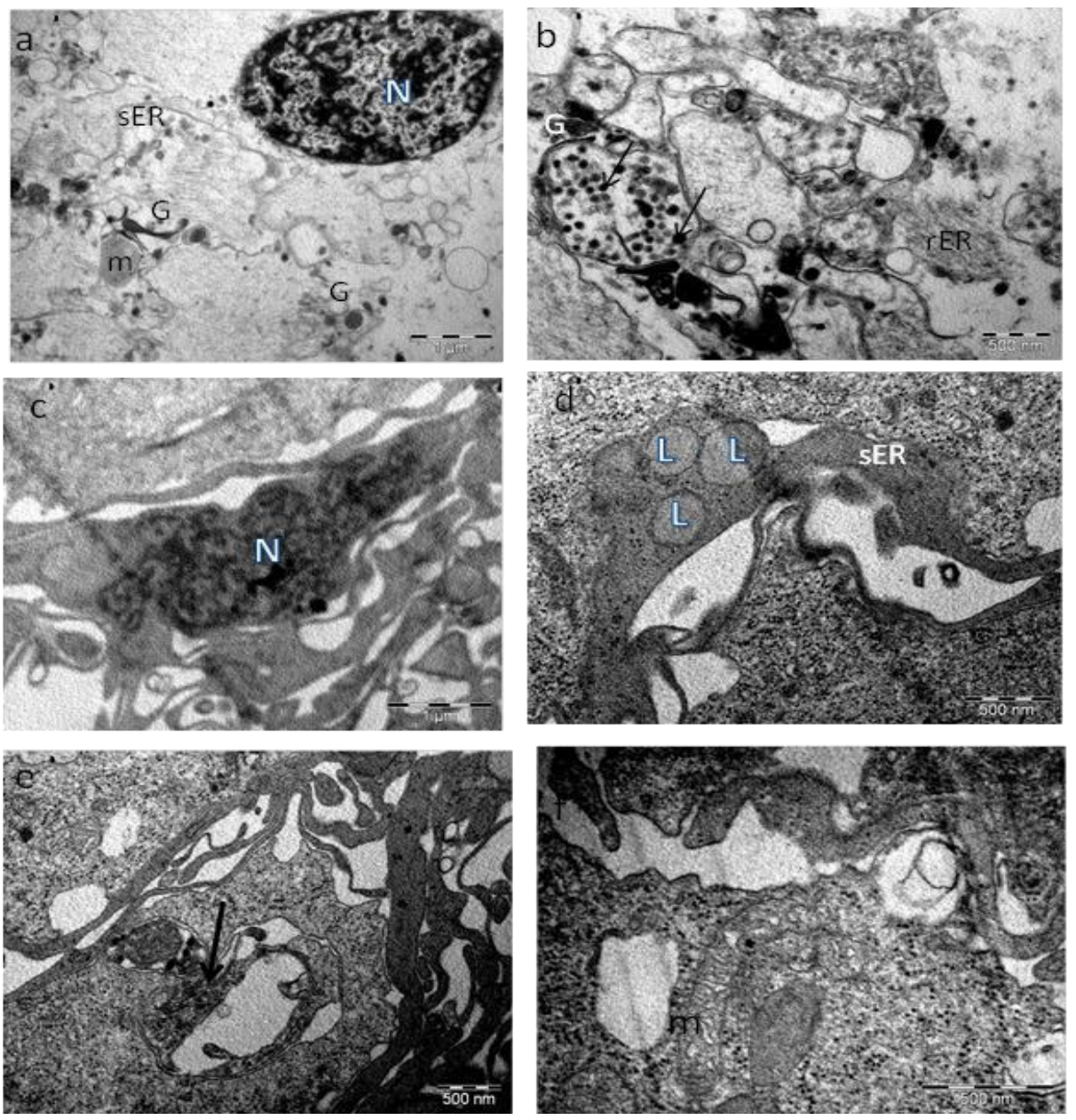

Fig. 2: Transmission electron micrographs of control Biomphalaria alexandrina central nervous system a,b showing (a) oval nucleus $(\mathrm{N})$, mitochondria (m), well-developed Golgi complex (G) and smooth endoplasmic reticulum ( sER). (b) A large varicosity is densely packed with large granular vesicles and rough endoplasmic reticulum ( $\mathrm{rER}$ ). After $24 \mathrm{~h}$ in $5 \mathrm{ml} / \mathrm{L}$ propofol $(\mathrm{c}, \mathrm{d}, \mathrm{e})$. (c) Irregular nucleus. (d) Lipid droplets (L) surrounded by (sER). (e) Shrunken process, varicosities have few granular vesicles (arrow). After $72 \mathrm{~h}$ in low concentration $1 \mathrm{ml} / \mathrm{L}$ propofol (f) Empty varicosities and elongated mitochondria (m).

\section{DISCUSSION}

This study is the first to demonstrate that anesthetic treatment effect on ultrastructure element of Biomphalaria alexandrina central nervous system. The present data demonstrated that the propofol-induced effect on morphology and ultrastructure of visceral and pedal ganglia of $B$. alexandrina which lead to suppression of synaptic transmission. These data are in contrast with previous studies on vertebrate neurons, where propofol did not significantly alter the responsiveness of either glutamate (Perouansky and Antognini, 2003) or glycine receptors (Daniels and Roberts, 1998). In agreement to the present study, Woodall et al. (2003) indicated that anesthetic treatment blocks synaptogenesis but not neuronal regeneration of cultured Lymnaea neuron. 
Browning and Lukowiak (2008) recorded that ketamine causes impairment of procedural memory formation, and that ketamine acts differentially, inhibiting only long-term memory (LTM) formation while having no effect on intermediate-term memory (ITM) formation. Ketamine's ability to inhibit LTM was found not to be due to state dependent learning implying that ketamine's effects are therefore specific to the molecular process involved in procedural LTM formation. This suggests that ketamine may be exerting its differential effects by altering the gene transcription processes necessary and specific for LTM formation. Additionally, ketamine was found to have no effect on retrieval when administered $1 \mathrm{~h}$ before testing.

Propofol has been found to inhibit endogenous glutamate release from endosomes (Perouansky and Hemmings, 2003) suggesting that it may also affect transmitter release though a similar action on intact, functional synapses has not yet been demonstrated. Other studies on rat hippocampal neurons in vitro (Orser et al., 1995) argue that propofol-induced suppression of synaptic transmission may be mediated indirectly through an enhancement of GABA receptor function (Bai et al., 2001; Hirota et al., 1998; Wakasugi et al., 1999; Pearce, 2003). This notion is consistent with a recent study, which demonstrates that propofol potentiates GABA ergic synaptic transmission in the brain and that these effects accompany neuronal activity-mediated, enhancement of $c$-fos expression (Nelson et al., 2002). As propofol and other anesthetics were found to affect GABAA receptors in the sleep pathway (Nelson et al., 2002), the preceding study thus further underscores the importance of such agents in defining normal patterns of neuronal activity in the nervous system. On the other hand, because mutant mice lacking the submit of the GABAA1- receptor still exhibit normal anesthesia in response to propofol, the precise site and the mode of this anesthetic's actions still remain controversial (Homanics and Firestone, 2003).

When action potentials were evoked, spike AHP was reduced in RPeD1, but not in VD4, by both propofol and ketamine. This illustrates the differential effects that pharmacological agents may have on identified neurones with different ion channel complements and also suggests that propofol and ketamine act on voltage dependent components of the neuronal membrane. Ketamine has already been shown to have voltage dependent effects (Parsons et al., 1995); this is unsurprising in view of its effects as an NMDA receptor antagonist. Changes in intracellular calcium are potentially important in the mediation of anaesthesia (Ahmed et al., 1993; Winlow et al., 1993). In one study, propofol was shown to increase intracellular calcium (Mantz et al., 1994), whereas another (Yamakage et al., 1995) reported a reduction in intracellular calcium transients by propofol and ketamine. Halothane and isoflurane have been shown to increase intracellular calcium in hippocampal neurones and also to have an effect on $\mathrm{K}_{-}$channels involved in the generation of spike AHP (Stapelfeldt and Oleszewski, 1999). Both menthol and inhalation anaesthetics have been shown previously to reduce AHP in RPeD1 (Haydon et al., 1982).

Syed and Winlow (1991) suggested underlying excitatory actions of propofol, particularly at lower concentrations, which may be specifically directed towards intrinsic 'bursting' mechanisms within the cell, with potential consequences for the emergent rhythmical output from the network as a whole. Similarly, the output of rhythm-generating neuronal networks may be an important target for anaesthetics in the mammalian CNS. For example, respiratory sinus arrhythmia, a manifestation of rhythmic output from the brainstem, has been shown to be significantly affected by 
propofol, providing a reliable indicator of depth of anaesthesia (Pomfrett et al., 1993).

The present data suggest that the vesicles are synthesized and filled at Golgi complexes, which are frequently observed in close association with vesicle groups, and often contained electron-dense material. This result was agreed with Turner et al., (1980).

In conclusion propofol has strong effect on ultrastructure feature of neuron cells. The nucleus became irregular in shape, the mitochondria changed from oval to elongated and poorly developed endoplasmic reticulum, few Golgi bodies which affecting on the presence of granular vesicles in varicosities in axon.

\section{ACKNOWLEDGMENT}

This study was supported by the internal project " 96 C" Theodor Bilharz Research institute, Giza, Egypt.

\section{Compliance with Ethical Standards:}

All applicable international, national, and/or institutional guidelines for the care and use of animals were followed. This article does not contain any studies with human participants performed by any of the authors.

Conflict of interest:

The authors declare that no conflict of interest.

\section{REFERENCES}

Ahmed, I.A.; Hopkins, P.M. and Winlow, W. (1993). Caffeine and ryanodine differentially modify a calciumdependent component of soma action potentials in identified molluscan neurones. Comp. Biochem. Physiol., 105C: 363-372.

Bai, D.; Zhu, G.; Pennefather, P.; Jackson, M.F.; Mac Donald, J.F. and Orser, B.A. (2001). Distinct functional and pharmacological properties of tonic and quantal inhibitory postsynaptic currents mediated by gamma-aminobutyric acid (A) receptors in hippocampal neurons. Mol Pharmacol., 59: 814-824.

Bogodvid, T.K.; Vyatcheslav, V.; Andrianov, V.V.; Deryabina, I.B.; Muranova, L.N.; Silantyeva, D.I.; Vinarskaya, A.; Balaban, P.M. and Gainutdinov, K.L. (2017). Responses of withdrawal interneurons to serotonin Applications in naïve and learned snails are different. Front. Cell. Neurosci., 1-10.

Browning, K. and Lukowiak, K. (2008). Ketamine inhibits long-term, but not intermediate-term memory formation in lymnaea stagnalis. neuroscience, 155 : 613-625.

Daniels, S. and Roberts, R.J. (1998). Post-synaptic inhibitory mechanisms of anesthesia; glycine receptors. Toxicol Lett, 100-101: 71-76

Elekes, K.; Hiripi, L.; Balog, G.; Maász, G.; Battonyai, I.; Khabarova, M.Y.; Horváth, R. and Voronezhskaya, E.E. (2018). Serotonergic regulation of the buccal (feeding) rhythm of the pond snail, Lymnaea stagnalis. An immunocytochemical, biochemical and pharmacological approach. Acta Biol. Hung., 69(3):225-243.

Hara, M.; Kai, Y. and Ikemoto, Y. (1993). Propofol activates GABAA receptor chloride ionophore complex in dissociated hippocampal pyramidal neurons of the rat. Anesthesiology, 79: 781-783.

Haydon, P.G.; Winlow, W. and Holden, A.V. (1982). The effects of menthol on central neurons of the pond snail Lymnaea stagnalis. Comp. Biochem. Physiol.,73C: 95-100. 
Hirota, K.; Roth, S.H.; Fujimura, J.; Masuda, A. and Ito Y. (1998). GABA ergic mechanisms in the action of general anesthetics. Toxicol Lett, 100-101: 203207.

Homanics, G.E. and Firestone, L.L. (2003). Genetic dissection of anesthetic action. In: Neural mechanisms of anesthesia, edited by Antognini JF, Carstens EE, and Raines DE. Totowa, NJ: Humana, 249-261.

Girdlestone, D.; Cruickshank, S.G.H. and Winlow, W. (1989a). The actions of 3 volatile anaesthetics on the withdrawal response of the pond snail Lymnaea stagnalis. Comp. Biochem. Physiol., 92C: 39-43.

Girdlestone, D.; McCrohan, C.R. and Winlow, W. (1989b). The actions of halothane on spontaneous activity, action potential shape and synaptic connections of the giant serotonin-containing neuron of Lymnaea stagnalis. Comp. Biochem. Physiol., 93C:333-339.

Glauert,A. M. (1974). The high voltage Electron Microscope in biology. J Cell Biol. 1974 Dec 1; 63(3): 717-748.

Kyriakides, M.A.; McCrohan, C.R.; Slade, C.T.; Syed, N.I. and Winlow, W. (1989). The morphology and electrophysiology of the neurons of the paired pedal ganglia of Lymnaea stagnalis. Comp. Biochem. Physiol., 93A: 861-876.

Mantz, J.; Delumeau, J.C.; Cordier, J. and Petitet, F. (1994). Differential effects of propofol and ketamine on cytosolic $\mathrm{Ca}$ concentrations of astrocytes in primary culture. Br. J. Anaesthesiol., 72: 351-353.

Mills, J.D.; McCrohan, C.R. and Bailey, S.E.R. (1992). Effects of metaldehyde and acetaldehyde on specific membrane currents in neurons of the pond snail Lymnaea stagnalis. Pest. Sci.,34: 243-247.

Nacsa, K.; Elekes,K. and Serf, Z. (2015). Ultrastructural localization of NADPH diaphorase and nitric oxidesynthase in the neuropils of the snail CNS. Micron, 75: 58-66.

Nelson, L.E.; Guo, T.Z.; Lu, J.; Saper, C.B.; Franks, N.P. and Maze, M. (2002). The sedative component of anesthesia is mediated by GABA(A) receptors in endogenous sleep pathway. Nat Neurosci., 5: 979-984.

Orser, B.A.; Bertlik, M.; Wang, L.Y. and MacDonald, J.F. (1995). Inhibition by propofol (2, 6 di-isopropylphenol) of the NMDA subtype of glutamate receptor in cultured hippocampal neurons. Br J. Pharmacol., 116: 1761-1768.

Orser, B.A.; Pennefather, P.S. and MacDonald, J.F. (1997). Multiple mechanisms of ketamine blockade of $N$ methyl- D-aspartate receptors. Anesthesiology, 86: 904-917.

Parsons, C.G.; Quack, G.; Bresink, I.; Baran, L.; Przegalinski, E.; Kostowski, W.; Krzascik, P.; Hartman, S. and Danysz, W. (1995). Comparison of the potency, kinetics and voltage-dependency of a series of uncompetitive $N$-methyl-Daspartate receptor antagonists in vitro with anticonvulsive and motor impairment activity in vivo. Neuropharmacology, 34: 1239-1258.

Pearce, R.A. (2003). General anesthetic effects on GABAA receptors. In: Neural mechanisms of anesthesia, edited by Antognini JF, Carstens EE, and Raines DE. Totowa, NJ: Humana, 265-282.

Perouansky, M. and Antognini, J.F. (2003). Glutamate receptors: physiology and anesthetic pharmacology. In: Neural mechanisms of anesthesia, edited by Antognini, JF, Carstens EE, and Raines DE. Totowa, NJ: Humana, pp. 319332. 
Perouansky, M. and Hemmings, H.C. (2003). Presynaptic actions of general anesthetics. In: Neural mechanisms of anesthesia, edited by Antognini, JF, Carstens EE, and Raines DE. Totowa, NJ: Humana, 345-369.

Pomfrett, C.J.D.; Barrie, J. R. and Healey, T.E.J. (1993). Respiratory sinus arrhythmia: an index of light anaesthesia. Br. J. Anaesthiol., 71: 212-217.

Stapelfeldt, W.H. and Oleszewski, J.M. (1999). Protein kinase-mediated reciprocal modulatory changes in anesthetic sensitivity of $(\mathrm{BK}) \mathrm{K}_{-}$and GABA-A receptor gated conductance in guinea pig sympathetic neurons. Toxicol. Lett., 100: 97102.

Syed, N.I. and Winlow, W. (1991). Respiratory behaviour in the pond snail Lymnaea stagnalis: neural elements of the central pattern generator. J. Comp. Physiol., 169: 557-568.

Turner, J.D.; Bpowell, B. and Cottrell, G. A. (1980). Morphology and ultrastructure of an identified histamine-containing neuron in the central nervous system of the pond snail Lymnaea stagnalis. Journal of Neurocytology, 9: 1-14.

Violet, J.; Downie, D.L.; Nakisa, R.C.; Lieb, W.R. and Franks, N.P. (1997). Differential sensitivities of mammalian neuronal and muscle nicotinic acetylcholine receptors to general anaesthetics. Anesthesia, 86: 866-874.

Wakasugi, M.; Hirota, K.; Roth S.H. and Ito Y. (1999). The effects of general anesthetics on excitatory and inhibitory synaptic transmission in area CA1 of the rat hippocampus in vitro. Anesth Analg, 88: 676-680.

Winlow, W.; Yar, T.; Spencer, G.E.; Girdlestone, D. and Hancox, J. (1993). Differential effects of general anaesthetics in situ and in culture. Gen. Pharmacol., 23: 985-992.

Woodall, A.J. and McCrohan, C.R. (2000). Excitatory actions of propofol and ketamine in the snail Lymnaea stagnalis. Comparative Biochemistry and Physiology Part C, 127: 297-305.

Woodall, A.J.; Naruo, H.; Prince, D.J.; Feng, Z.P.; Winlow,W.; Takasaki, M.; and Syed, N.I. (2003). Anesthetic treatment blocks synaptogenesis but not neuronal regeneration of cultured Lymnaea neurons. J. Neurophysiol., 90: 2232-2239.

Wu, M.H.; Su, M.J. and Sun, S.S.M. (1997). Comparative electrophysiological effects of propofol on the conduction system and ionic channels of rabbit hearts Br. J. Pharmacol., 121: 617-624.

Wyeth, R.C. (2019). Olfactory navigation in aquatic gastropods. J. Exp. Biol., 222 (Suppl 1).

Yamakage, M.; Hirschmann, C.A. and Croxton, T.L. (1995). Inhibitory effects of thiopental, ketamine and propofol on voltage-dependent Ca channels in porcine tracheal smooth muscle cells. Anesthesiology, 83: 1274-1282. 


\title{
ARABIC SUMMARY
}

\section{تأثير البروبوفول فريسينسيس 1\% على التركيب الدقيق للجهاز العصبى لقواقع Biomphalaria} alexandrina

\author{
حنان شحات مسلم و شيرين محفوظ منصور

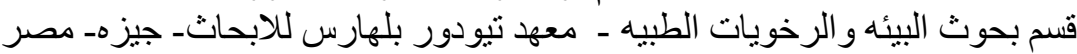

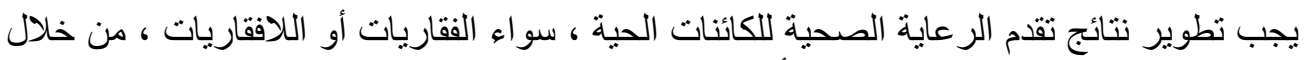

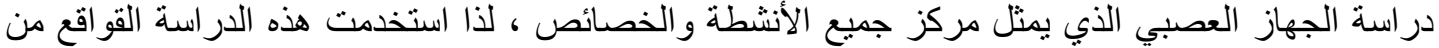

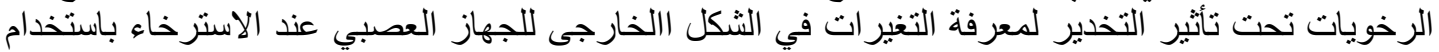

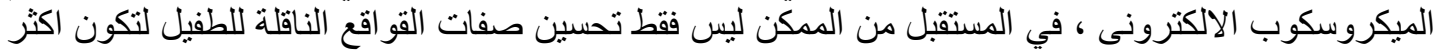

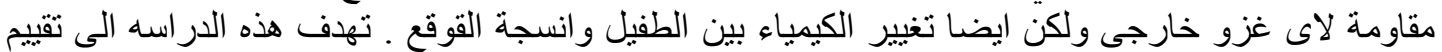

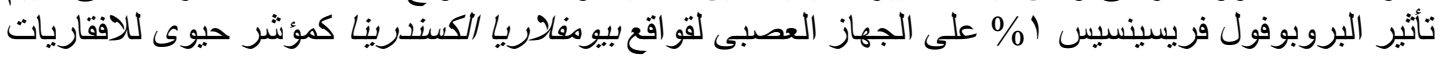

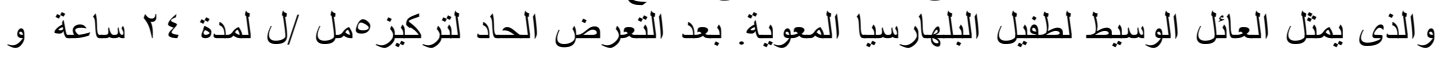

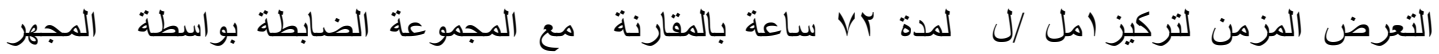

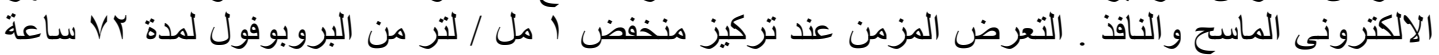

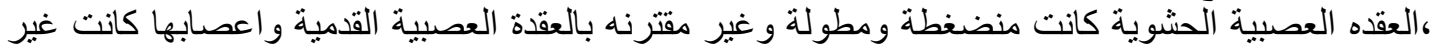

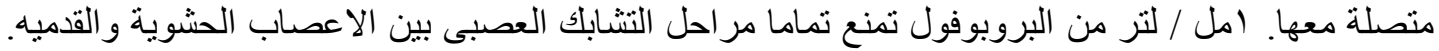

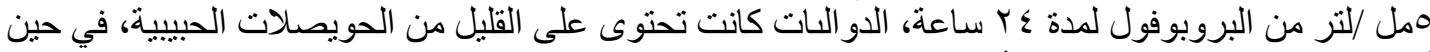

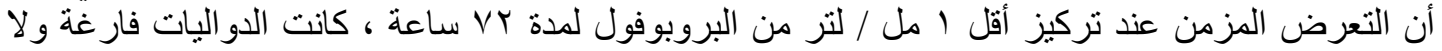

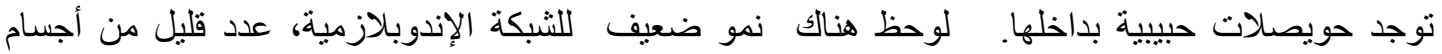
جولجى، مينوكوندريا مطوله و مساحات كبيرة بين الخلايا. 